Article

\title{
The Ethanol Oxidation Reaction Performance of Carbon-Supported PtRuRh Nanorods
}

\author{
Tzu-Hsi Huang ${ }^{1}$, Dinesh Bhalothia ${ }^{2} \mathbb{D}$, Shuan Lin ${ }^{1}$, Yu-Rewi Huang ${ }^{1}$ and Kuan-Wen Wang ${ }^{1, *}$ \\ 1 Institute of Materials Science and Engineering, National Central University, Taoyuan 320, Taiwan; \\ candy10416@hotmail.com.tw (T.-H.H.); linshiuan@gapp.nthu.edu.tw (S.L.); \\ k03310401@hotmail.com (Y.-R.H.) \\ 2 Department of Engineering and System Science, National Tsing Hua University, Hsinchu 30013, Taiwan; \\ dinesh@mx.nthu.edu.tw \\ * Correspondence: kuanwen.wang@gmail.com
}

Received: 7 May 2020; Accepted: 1 June 2020; Published: 5 June 2020

\begin{abstract}
In this study, carbon-supported Pt-based catalysts, including PtRu, PtRh, and PtRuRh nanorods (NRs), were prepared by the formic acid reduction method for ethanol oxidation reaction (EOR) application. The aspect ratio of all experimental NRs is 4.6. The X-ray photoelectron spectroscopy and $\mathrm{H}_{2}$-temperature-programmed reduction results confirm that the ternary PtRuRh has oxygen-containing species (OCS), including $\mathrm{PtO}_{\mathrm{x}}, \mathrm{RuO}_{\mathrm{x}}$ and $\mathrm{RhO}_{\mathrm{x}}$, on its surface and shows high EOR current density at $0.6 \mathrm{~V}$. The corresponding physical structure results indicate that the surface OCS can enhance the adsorption of ethanol through bi-functional mechanism and thereby promote the EOR activity. On the other hand, the chronoamperometry (CA) results imply that the ternary PtRuRh has the highest mass activity, specific activity, and stability among all catalysts. The aforementioned pieces of evidence reveal that the presence of OCS facilitates the oxidation of adsorbed intermediates, such as $\mathrm{CO}$ or $\mathrm{CH}_{\mathrm{x}}$, which prevents the Pt active sites from poisoning and thus simultaneously improves the current density and durability of PtRuRh NRs in EOR.
\end{abstract}

Keywords: PtRuRh; ethanol oxidation reaction; nanorods; bi-functional mechanism; oxygen containing species

\section{Introduction}

Ethanol is one of the most promising sustainable energy in the future owing to its high energy density, non-toxicity, renewability, [1] and low green-house gas emission while produced [2,3]. However, the high bond dissociation energy of carbon-carbon bond $(C-C)$ in ethanol is a critical challenge for ethanol oxidation reaction (EOR), which also hinders the commercialization of direct ethanol fuel cell (DEFC). Therefore, much effort has been made to promote the EOR performance of catalysts.

The oxidation of ethanol produces several products in which acetaldehyde and acetic acid are formed through 2 and 4 electrons $\left(\mathrm{e}^{-}\right)$transfer, respectively [4]. However, the desire pathway is to form $\mathrm{CO}_{2}$ as a product, which not only requires $12 \mathrm{e}^{-}$transfer, but also involves the cleavage of the $\mathrm{C}-\mathrm{C}$ bond. Several undesired intermediates, such as $\mathrm{CO}_{\mathrm{ad}}$ and $\mathrm{CH}_{\mathrm{x}, \mathrm{ad}}$, may be produced during the $12 \mathrm{e}^{-}$transfer, poisoning the state-of-the-art anode Pt catalysts [5-9]. Generally, EOR on Pt catalysts starts from the dissociative adsorption of ethanol as described in Equation (1).

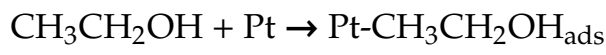

Pt then will be poisoned by undesired intermediates as shown in Equation (2).

$$
\mathrm{Pt}-\mathrm{CH}_{3} \mathrm{CH}_{2} \mathrm{OH}_{\mathrm{ads}} \rightarrow \mathrm{Pt}-\mathrm{CO}_{\mathrm{ads}}+\mathrm{CH}_{3}+3 \mathrm{H}^{+}+3 \mathrm{e}^{-}
$$


Therefore, in order to prevent the poisoning of Pt catalysts, binary catalysts are employed to improve the $\mathrm{CO}$ tolerance of $\mathrm{Pt}$ catalysts for EOR, especially alloying or modifying $\mathrm{Pt}$ with oxophilic metals, such as Sn [10-14] and Ru [10,14,15]. The presence of these oxophilic metal atoms can combine with oxygen-containing species (OCS), such as hydroxyl species $\left(\mathrm{OH}^{-}\right)$, which can further facilitate not only the incomplete oxidation of ethanol into acetic acid or $\mathrm{CO}_{2}$ through so called bifunctional mechanism but also the anti-poisoning ability of Pt catalysts [16,17] described in Equations (3)-(5):

$$
\begin{gathered}
\mathrm{Ru}(\text { or } \mathrm{Sn})+\mathrm{H}_{2} \mathrm{O} \rightarrow \mathrm{Ru}\left(\text { or Sn) }-\mathrm{OH}_{\mathrm{ads}}+\mathrm{H}^{+}+\mathrm{e}^{-}\right. \\
\mathrm{Pt}-\mathrm{CH}_{3} \mathrm{CHO}_{\mathrm{ads}}+\mathrm{OH}_{\mathrm{ads}} \rightarrow \mathrm{Pt}+\mathrm{CH}_{3} \mathrm{COOH}+\mathrm{H}^{+}+\mathrm{e}^{-} \\
\mathrm{Pt}-\mathrm{CO}_{\mathrm{ads}}+\mathrm{Ru} \text { (or Sn)-OH } \mathrm{OHd}_{\mathrm{ds}} \rightarrow \mathrm{Pt}+\mathrm{Ru} \text { (or Sn) }+\mathrm{CO}_{2}+\mathrm{H}^{+}+\mathrm{e}^{-}
\end{gathered}
$$

Therefore, alloying with oxophilic metal(s) is an efficient way to enhance the tolerance to poisoning intermediates for Pt catalysts. It has been reported that for [14] Pt/C, Pt-Ru (1:1) and Pt-Sn/C (3:1) catalysts, the oxidation of the adsorbed OCS is facilitated at lower potentials through supplying oxygen atoms from $\mathrm{Ru}$ or $\mathrm{Sn}$ oxides at an adjacent site.

The $\mathrm{PtRu} / \mathrm{C}$ catalyst is the state-of-the-art anode catalyst in direct methanol fuel cells and DEFC, owing to its remarkable $\mathrm{CO}$ tolerance that is usually ascribed to the bifunctional mechanism and ligand effects. The bifunctional mechanism is ascribed to the facilitation of $\mathrm{CO}_{\text {ads }}$ oxidation on Pt by OCS from $\mathrm{Ru}$ at low potentials, and the ligand effect suggests that the electronic structure of $\mathrm{Pt}$ is modified through formation of PtRu alloy, weakening CO adsorption on Pt [18-21]. However, Ru is easily dissolved into acid medium during the long-term operation of DEFC, which may degrade the CO tolerance and durability [22].

Besides PtRu/C catalysts, other binary and ternary catalysts, such as PtAu [23,24], PtAg [25,26], PtNi [27,28], PtRh [29,30], PtSnRh [31,32] and PtRuSn [33-35], have shown enhanced EOR performance attributed to the bifunctional mechanism and synergistic effect. Among them, $\mathrm{PtRh} / \mathrm{C}[36,37]$ catalysts are regarded as the promising catalysts to decompose ethanol. Although theoretical studies suggest that $\mathrm{Rh}$ is not as active as $\mathrm{Ru}$ for OCS formation, Rh can enhance the EOR performance of Pt-based catalysts by synergistic effects and electron modification [38].

Moreover, the $\mathrm{PtRuRh} / \mathrm{C}$ catalysts with different $\mathrm{Pt} / \mathrm{Ru} / \mathrm{Rh}$ compositions have been prepared for methanol oxidation reaction (MOR) $[39,40]$. It can be observed that the ternary PtRuRh can provide higher MOR activity than binary PtRu at low potential. Furthermore, the catalysts prepared at the ratio of $\mathrm{Pt}_{1} \mathrm{Ru}_{1} \mathrm{Rh}_{2}$ possess the highest current density at $0.5 \mathrm{~V}$ (vs. RHE) in $0.5 \mathrm{M} \mathrm{H}_{2} \mathrm{SO}_{4}$ and $1 \mathrm{M}$ $\mathrm{CH}_{3} \mathrm{OH}$ at $60^{\circ} \mathrm{C}$, suggesting the synergistic effect of $\mathrm{Ru}$ and $\mathrm{Rh}$ addition on their MOR performance. Therefore, ternary $\mathrm{PtRuRh} / \mathrm{C}$ can be a promising EOR catalyst.

Moreover, controlling the morphologies of $\mathrm{Pt}$ nanostructure is a promising method to promote their catalytic activity, especially the structure-sensitive reactions, such as EOR [41,42]. The Pt 1-D structures, such as nanorods (NRs) and nanowires (NWs), exhibit higher catalytic activities toward MOR and EOR when compared with 0-dimensional NPs [43]. This can be attributed to its anisotropic nature, high aspect ratios, few lattice boundaries and low surface defect sites [44-46]. Pt NWs can display lower onset potential and higher current density than Pt NPs, attributed to a decrease in the activation energy for EOR of 1-D structures [47]. Similar enhanced EOR performances can be observed on PtRh NWs [48]. PtRh NWs have obviously lower onset potential and higher activity than PtRh NPs and $\mathrm{Pt} / \mathrm{C}$. After 2000 cycles, the PtRh NWs maintains $86 \%$ current density, which is the most durable catalyst among the prepared ones. It seems that 1-D structures such as NWs or NRs with second metals can possess higher activity and stability than NPs, which may be associated with unique structure and surface properties.

In order to prepare highly effective catalysts, in this study, carbon-supported PtRu, PtRh, and $\mathrm{PtRuRh}$ catalysts have been prepared by taking the advantages of the bifunctional mechanism and 1-D 
structure. The presence of OCS can help the desorption of adsorbed intermediates on Pt active sites, which enhances the activity and stability of Pt catalyst, and 1-D structures with high aspect ratios can have better EOR performance than NPs, owing to its anisotropy and unique structure. The compositions, structures, morphologies, surface compositions and electrochemical performances of the prepared catalysts are analyzed by a field emission scanning electron microscope and an X-ray energy dispersive spectrometer (SEM-EDS), X-ray diffraction (XRD), transmission electron microscopy (TEM), X-ray photoelectron spectroscopy (XPS)/ $\mathrm{H}_{2}$-temperature-programmed reduction (TPR)/CO-stripping/cyclic voltammograms (CV), and linear sweep voltammograms (LSV)/ chronoamperometry (CA), respectively.

\section{Experimental Section}

\subsection{Preparation of Carbon-Supported Pt and Pt-Based NRs}

Carbon-support Pt, PtRu, PtRh, PtRuRh NRs with metal loading of 50 wt. \% were prepared through the formic acid method (FAM). For of Pt NRs, $0.05 \mathrm{~g}$ carbon black (Vulcan XC-72R) was dispersed in the deionized the preparation (DI) water for half an hour and then aqueous solution of $\mathrm{H}_{2} \mathrm{PtCl}_{6}$ and formic acid were added into the above solution at $288 \mathrm{~K}$ for 3 days. The as-deposited solution was then filtered, washed with DI, dried in $333 \mathrm{~K}$ oven overnight, and named as Pt.

For the preparations of binary PtRu and PtRh, $0.05 \mathrm{~g}$ carbon black was dispersed in the DI, and then $\mathrm{H}_{2} \mathrm{PtCl}_{6}$ and formic acid were added into the solution at $288 \mathrm{~K}$ for 3 days. The second metal precursor $\left(\mathrm{RuCl}_{2}\right.$ or $\left.\mathrm{RhCl}_{3}\right)$ and isopropanol (IPA) as a reductant were added into the as-deposited $\mathrm{Pt}$ solutions at $288 \mathrm{~K}$ for another 2 days. The as-deposited solution containing $\mathrm{RuCl}_{2}$ or $\mathrm{RhCl}_{3}$ was then filtered, washed with DI, dried in $333 \mathrm{~K}$ oven overnight, and named as PtRu and PtRh, respectively.

For the preparation of ternary PtRuRh catalysts, $\mathrm{RhCl}_{3}$ was added into the as-deposited PtRu solution and reacted for another 2 days at $288 \mathrm{~K}$. The as-deposited solutions were filtered, washed with DI and dried at $333 \mathrm{~K}$.

\subsection{Characterizations of the Catalysts}

The atomic compositions of catalysts were characterized by a field emission scanning electron microscope (JSM7000F) and an X-ray energy dispersive spectrometer (SEM-EDS, Bruker) operated at $15 \mathrm{kV}$. The phases and structures of prepared catalysts were analyzed by the X-ray diffraction (XRD) with $\mathrm{CuK} \alpha$ radiation operated $40 \mathrm{kV}$ and $25 \mathrm{~mA}$ at a scan rate of $3^{\circ} \mathrm{min}^{-1}$. In order to calculate d-spacing, Bragg's law was applied:

$$
\mathrm{n} \lambda=2 d \sin \theta
$$

where $n$ is positive integer, $\lambda$ is the wavelength of radiation source, $\theta$ is the diffraction angle and $d$ is the d-spacing. In addition, for the face-centered cubic crystal style, the lattice parameter can be determined by the relationship of Equation (7):

$$
d=\frac{a}{\sqrt{1^{2}+\mathrm{m}^{2}+\mathrm{n}^{2}}}
$$

where $\mathrm{l}, \mathrm{m}$ and $\mathrm{n}$ are the Miller index, $\mathrm{d}$ is the $\mathrm{d}$-spacing value and $\mathrm{a}$ is the lattice parameter. In order to obtain the grain size, Schreer's equation was applied [49]:

$$
\tau=\frac{\mathrm{K} \lambda}{\beta \cos \theta}
$$

where the $\tau$ is mean grain size, $K$ is constant, $\lambda$ is the wavelength of radiative source, $\beta$ is the full width at half maximum of the base peak and $\theta$ is the diffraction angle.

The morphologies of catalysts were confirmed by high-resolution transmission electron microscopy (HRTEM, JOEL-2100) operated at $160 \mathrm{kV}$. The catalysts powders were prepared by ultrasonically suspending in IPA. Afterward, the suspension was then dropped on 200 mesh copper grids. 
The surface chemical states of various catalysts were analyzed by X-ray photoelectron spectroscopy (XPS, Thermo VG Scientific Sigma Probe) using an AlK $\alpha$ radiation at a voltage of $20 \mathrm{kV}$ and a current of $30 \mathrm{~mA}$. The surface compositions and chemical states of the samples are calculated by integral of each peak and a combination of Lorentzian and Gaussian lines was applied to fit the experimental curves. $\mathrm{C} 1 \mathrm{~s}$ peak at $284.6 \mathrm{eV}$ was used as an internal standard to determine the accurate binding energies.

The surface species of the prepared catalysts were characterized by the $\mathrm{H}_{2}$-temperatureprogrammed reduction (TPR). The variations of hydrogen contents during the flowing of the reduction gas are detected by a thermal conductivity detector (TCD). The sample of $0.1 \mathrm{~g}$ was reduced by a flow of $20 \% \mathrm{H}_{2}$ in $\mathrm{N}_{2}$ at the flow rate of $50 \mathrm{~mL} \mathrm{~min}^{-1}$ while raising the temperature from 150 to $600 \mathrm{~K}$ at the heating rate of $7 \mathrm{~K} \mathrm{~min}^{-1}$.

Electrochemical measurements through a $\mathrm{CH}$ Instruments Model 611c device were operated to analyze the performance of prepared catalysts. The counter and reference electrodes were Pt plate and saturated calomel electrode (SCE), respectively. The catalysts in IPA and Nafion solution (5 wt. \%, DuPont) were dispersed and dropped on a glass carbon electrode as working electron. CO-stripping was operated by purging $\mathrm{CO}$ gas in $0.5 \mathrm{M} \mathrm{H}_{2} \mathrm{SO}_{4}$ for $30 \mathrm{~min}$ before the experiment; while operating, $\mathrm{CO}$ was kept purging at $-0.1 \mathrm{~V}$ (vs. SCE) for $30 \mathrm{~min}$, then CO-stripping was measured between -0.3 and $0.76 \mathrm{~V}$ (vs. SCE) at the rate of $50 \mathrm{mV} \mathrm{s}^{-1}$ in $\mathrm{N}_{2}$ saturated $0.5 \mathrm{M} \mathrm{H}_{2} \mathrm{SO}_{4}$ The electrochemically active surface area calculated form $\mathrm{CO}$-stripping $\left(\mathrm{ECSA}_{\mathrm{CO}}\right)$ is defined by the Equation (9):

$$
E C S A_{C O}=\frac{Q_{C O}}{[P t] \times 0.42}
$$

where $[\mathrm{Pt}]$ presents the $\mathrm{Pt}$ loading on the electrode, $\mathrm{Q}_{\mathrm{CO}}$ indicates the charge for $\mathrm{CO}$-desorption and 0.42 is assuming that the oxidation of a CO monolayer requires $0.42 \mathrm{mC} / \mathrm{m}^{2}$ [50].

Cyclic voltammograms (CV) were swept between -0.24 and $1.0 \mathrm{~V}$ (vs. SCE) at the rate of $50 \mathrm{mVs}^{-1}$ in $0.5 \mathrm{M} \mathrm{H}_{2} \mathrm{SO}_{4}$ purged with $\mathrm{N}_{2}$ for $30 \mathrm{~min}$ to ensure the electrolyte is $\mathrm{N}_{2}$-saturated. The ECSA by $\mathrm{H}$-adsorption $\left(\mathrm{ECSA}_{\mathrm{H}}\right)[50,51]$ was calculated by integrating the areas of hydrogen desorption at $0-0.4 \mathrm{~V}\left(\mathrm{Q}_{\mathrm{H}}\right)$. The values were obtained from the following Equation (10):

$$
E C S A_{H}=\frac{Q_{H}}{[P t] \times 0.21}
$$

where $0.21\left(\mathrm{mC} / \mathrm{m}^{2}\right)$ is the charge required to oxidize a monolayer of $\mathrm{H}_{2}$ on Pt active sites. For the EOR activity, the CVs were swept between -0.24 to $1.0 \mathrm{~V}$ (vs. SCE) with a scanning rate of $2 \mathrm{mVs}^{-1}$ in $0.5 \mathrm{M}$ $\mathrm{H}_{2} \mathrm{SO}_{4}$ and $1 \mathrm{M} \mathrm{C}_{2} \mathrm{H}_{5} \mathrm{OH}$ saturated with $\mathrm{N}_{2}$. The durability tests of the catalysts were measured at consist voltage of $0.36 \mathrm{~V}$ (vs. SCE) for 2 hrs by chronoamperometric (CA), and the electrolyte for LSV and CA was both $\mathrm{N}_{2}$-saturated $0.5 \mathrm{M} \mathrm{H}_{2} \mathrm{SO}_{4}$ containing $1.0 \mathrm{M} \mathrm{C}_{2} \mathrm{H}_{5} \mathrm{OH}$.

\section{Results and Discussion}

The exact compositions of PtRu, PtRh, and PtRuRh determined by SEM-EDS are displayed in Table S1. It seems that by the FAM process, carbon supported PtRu, PtRh, and PtRuRh catalysts can be prepared.

The structural information of PtRu, PtRh, and PtRuRh catalysts obtained by XRD is shown in Figure S1. The peaks of XC-72R carbon black are located at $25^{\circ}$ for all catalysts. For the Pt catalysts, peaks located at $39.80^{\circ}, 46.28^{\circ}$ and $67.53^{\circ}$ are attributed to the (111), (200) and (220) planes of face-centered cubic (fcc) Pt, respectively, (JCPDS 870646). For PtRu and PtRh, the characteristic peaks are located at $40.23^{\circ}, 46.70^{\circ}$ and $68.03^{\circ}$, which are obviously shifted to larger angle when compared to the $\mathrm{Pt}$ reference, owing to the smaller atomic radius of $\mathrm{Ru}(134 \mathrm{pm})$ and $\mathrm{Rh}(134 \mathrm{pm})$ than that of $\mathrm{Pt}$ $(139 \mathrm{pm})$ and lattice shrinkage during alloying. In terms of the ternary catalysts, the peaks are located at $40.63^{\circ}, 47.07^{\circ}$ and $68.40^{\circ}$ for PtRuRh. The d-spacing calculation results are around $0.227,0.224,0.224$, and $0.222 \mathrm{~nm}$ for $\mathrm{Pt}, \mathrm{PtRu}, \mathrm{PtRh}$, and PtRuRh, respectively. 
The decrease in d-spacing in binary and ternary catalysts demonstrates that $\mathrm{Ru}$ and $\mathrm{Rh}$ atoms partially substitute $\mathrm{Pt}$ atoms in the structure. The calculated lattice parameters for catalysts are listed in Table S1, in which the prepared binary and ternary catalysts have the lattice parameter of $0.384 \mathrm{~nm}$ compared to $0.392 \mathrm{~nm}$ for Pt, related to the alloying and EOR enhancement [52]. The calculated mean grain sizes for Pt, PtRu, PtRh, and PtRuRh are 5.3, 4.6, 4.6, and $4.8 \mathrm{~nm}$, respectively.

Figure 1 presents the morphologies of Pt, PtRu, PtRh, and PtRuRh by HRTEM. From Figure 1a-d, it can be observed that various NRs can be successfully prepared by FAM, in which the mean aspect ratios of $\mathrm{Pt}, \mathrm{PtRu}, \mathrm{PtRh}$, and $\mathrm{PtRuR}$ is $4.5 \pm 0.9,4.7 \pm 0.9,4.5 \pm 0.8$, and $4.7 \pm 0.8$, respectively. Figure 1e-h shows the morphologies after CA test, in which the mean aspect ratios of catalysts shorten into $2.1 \pm 0.7,2.1 \pm 0.6,1.8 \pm 0.6$, and $2.0 \pm 0.7$ for Pt, PtRu, PtRh, and PtRuRh, respectively, as summarized in Figure 1i-l, suggesting that during CA test, the catalysts suffer from dissolution, migration, corrosion, etc.
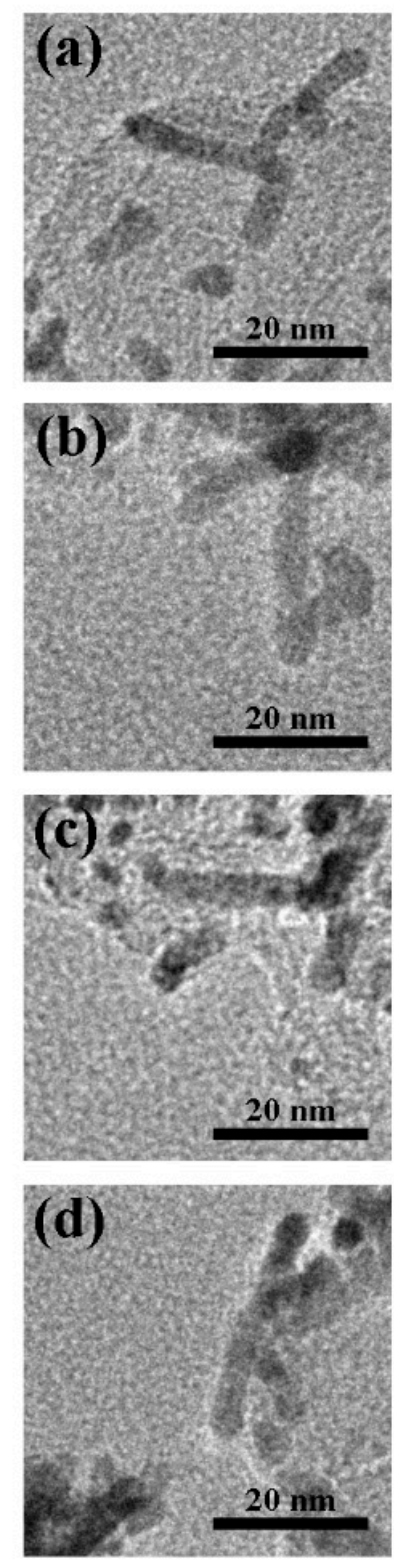
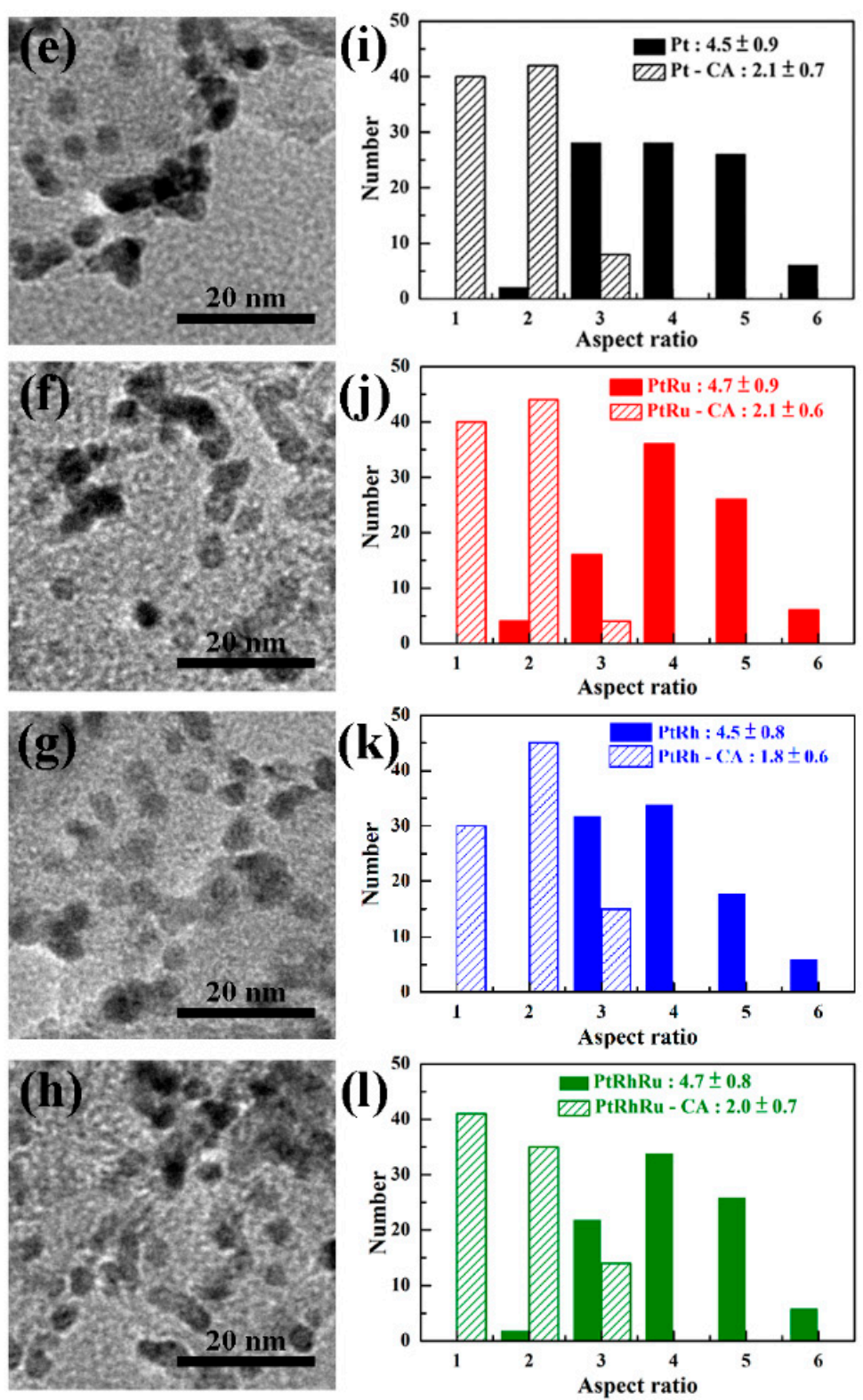

Figure 1. High-resolution transmission electron microscopy (HRTEM) micrographs of morphologies before CA: (a) Pt (b) PtRu, (c) PtRh and (d) PtRuRh; after CA: (e) Pt, (f) PtRu, (g) PtRh and (h) PtRuRh; aspect ratios distributions: (i) Pt, (j) PtRu, (k) PtRh and (1) PtRuRh. 
The XPS spectra of Pt, PtRu, PtRh, and PtRuRh catalysts analyzed by XPS are displayed in Figure 2 and their surface compositions are listed in Table S2. In Figure 2, the Pt peaks located at 71.0 and $74.3 \mathrm{eV}$ belong to $4 f_{7 / 2}$ and $4 f_{5 / 2}$, respectively. For other binary and ternary catalysts, slight shifts are noted due to different degrees of electron transfer between Pt and the second or third metals [53,54]. Moreover, the addition of the second metals influences the chemical states of Pt in which the Pt oxide compositions increase or decrease owing to the Ru or Rh addition, respectively. Meanwhile, the amount of OCS, such as $\mathrm{PtO}_{x}, \mathrm{RuO}_{\mathrm{x}}$, or $\mathrm{RhO}_{\mathrm{x}}$, is also influenced and the EOR performances are also affected. It has been reported that the presence of $\mathrm{Ru}$ can modify the surface electronic structure of $\mathrm{Pt}$, causing the downshift of the $\mathrm{Pt} \mathrm{d}$-band center, weakening the interaction between $\mathrm{Pt}$ and absorbed intermediate species, and enhancing the EOR durability of Pt-based catalysts [55]. Therefore, such OCS plays an important role in determining the EOR performance.
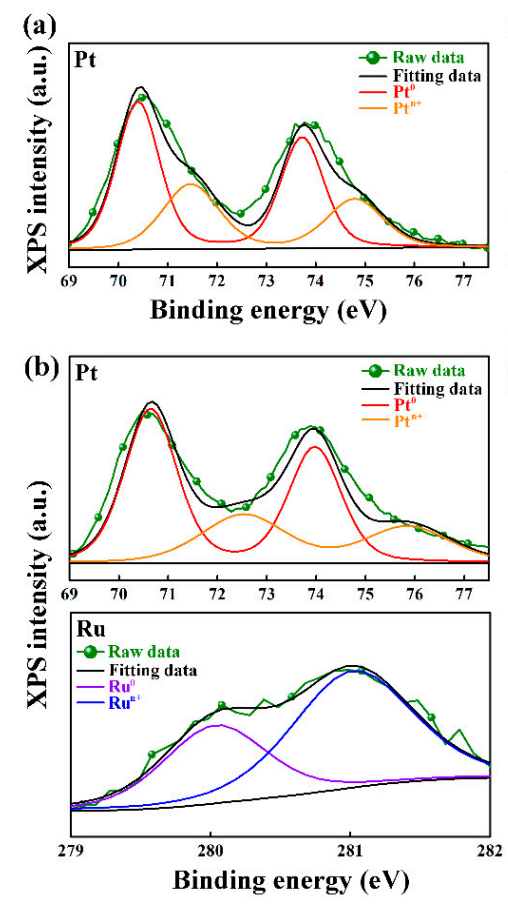

(c)

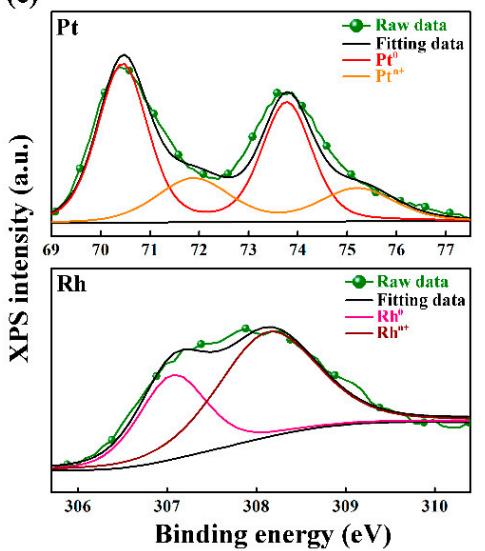

Binding energy $(\mathrm{eV})$ (d)
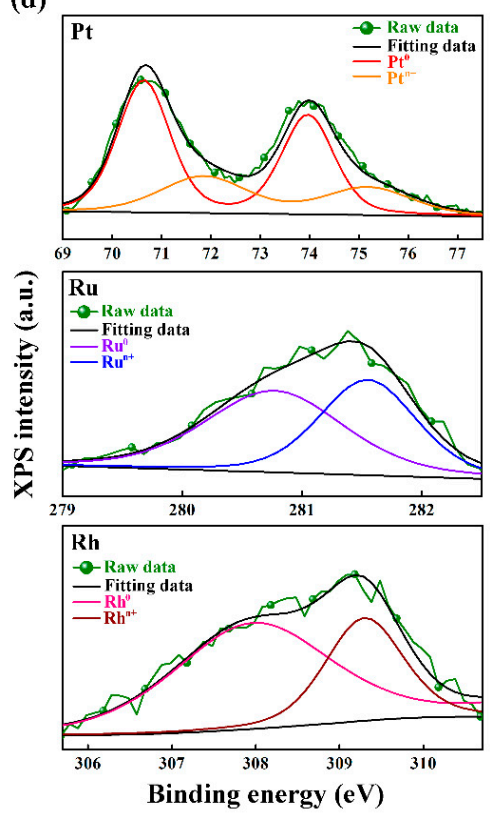

Figure 2. X-ray photoelectron spectroscopy (XPS) spectra of (a) Pt, (b) PtRu, (c) PtRh, and (d) PtRuRh.

On the other side, the TPR experiments are carried out to analyze the topmost surface species of the catalysts. The TPR spectra of PtRu, PtRh, and PtRuRh are displayed in Figure 3. The main reduction peaks for the catalysts located between 200 and $230 \mathrm{~K}$ are assigned to the reduction of the surface platinum oxides $\left(\mathrm{PtO}_{\mathrm{x}}\right)$. For the reduction of ruthenium oxides $\left(\mathrm{RuO}_{\mathrm{x}}\right)$ and rhodium oxides $\left(\mathrm{RhO}_{\mathrm{x}}\right)$, the reduction peaks are located between 300 and $400 \mathrm{~K}[56,57]$ and above $500 \mathrm{~K}$, respectively. The peak located at $250 \mathrm{~K}$ for PtRh may be owing to the reduction of surface PtRh alloy oxide ( $\left.\mathrm{A}^{\mathrm{PtRh}}\right)$. Therefore, the main surface species of $\mathrm{PtRuRh}$ is $\mathrm{Pt} / \mathrm{Ru} / \mathrm{Rh}$.

The CO-stripping experiments are performed, and the results for $\mathrm{Pt}, \mathrm{PtRu}, \mathrm{PtRh}$, and $\mathrm{PtRuRh}$ are displayed in Figure 4a and Table S3. It is obvious that the onset potential of $\mathrm{Pt}$ is much higher than those of the binary and ternary catalysts, implying a more effective $\mathrm{CO}$ oxidation reaction for the latter ones. Overall, PtRu performs the lowest onset potential, followed by PtRuRh $<<\mathrm{PtRh}$ [58-62], indicating that the incorporation of second or third metal can indeed enhance the $\mathrm{CO}$ oxidation by the bi-functional mechanism. On the other side, the ECSA $\mathrm{CO}_{\mathrm{C}}$ is compared in Table S3 in which PtRuRh has the largest value among all catalysts, suggesting that PtRuRh can provide the largest $\mathrm{Pt}$ surface area for $\mathrm{CO}$ oxidation. Besides, it has been reported that $\mathrm{RuO}_{x}$ helps the desorption of $\mathrm{CO}$ adsorbed on $\mathrm{Pt}$ [63]. Thus, it appears that PtRuRh is superior to promote the electro-oxidation of adsorbed CO than other samples. 


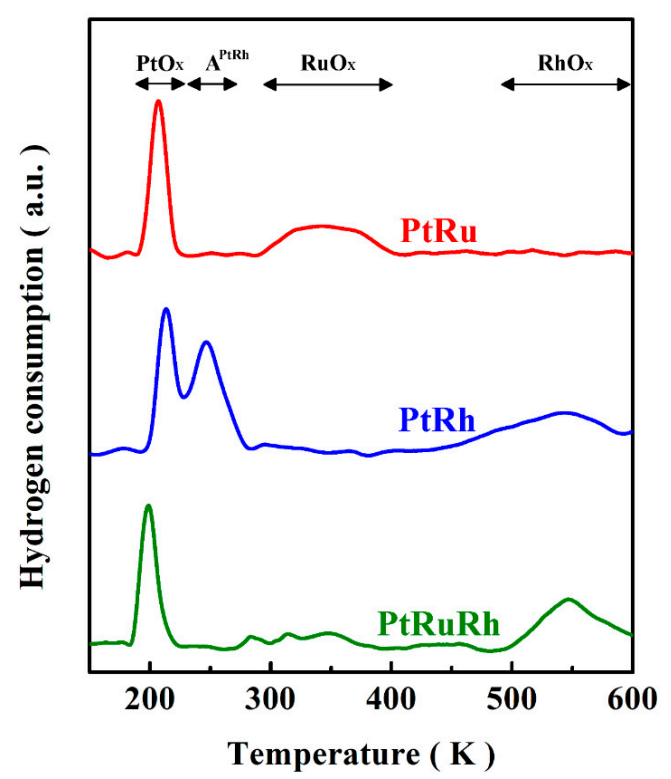

Figure 3. Temperature-programmed reduction (TPR) traces of PtRu, PtRh, and PtRuRh.

(a)

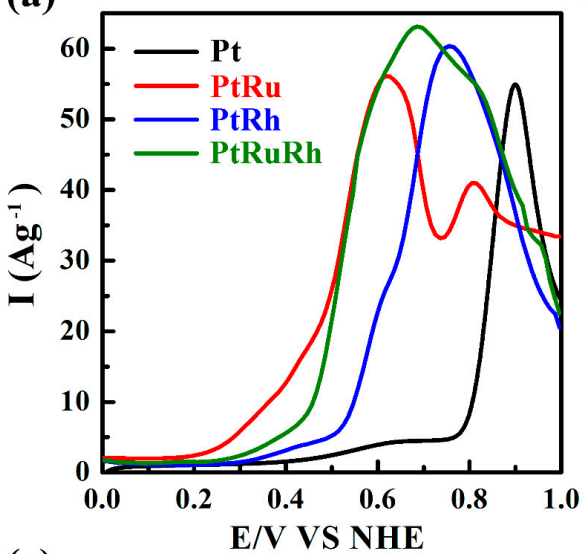

(c)

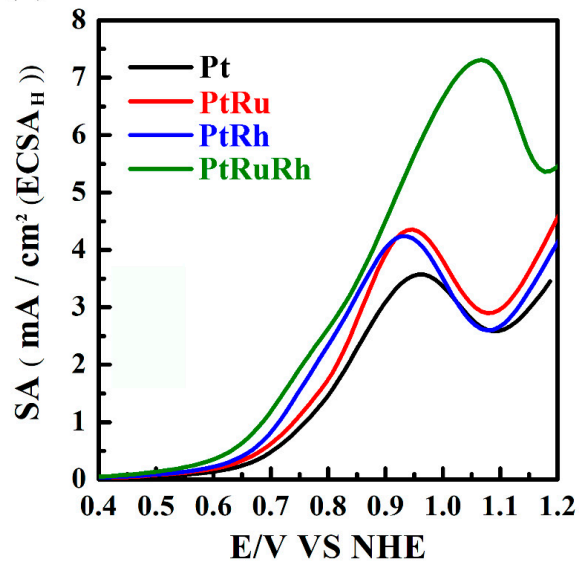

(b)

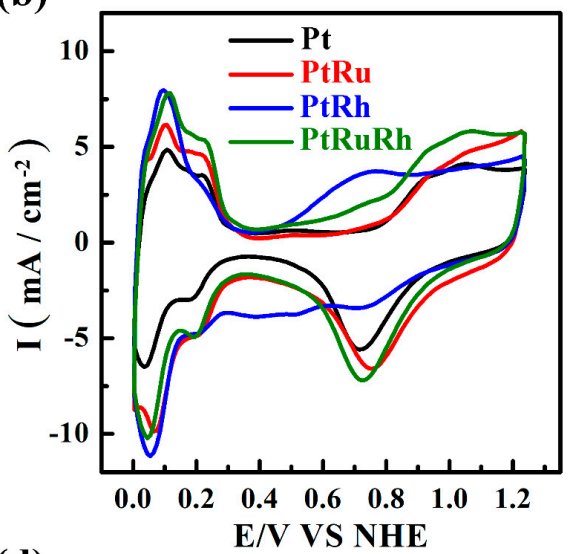

(d)

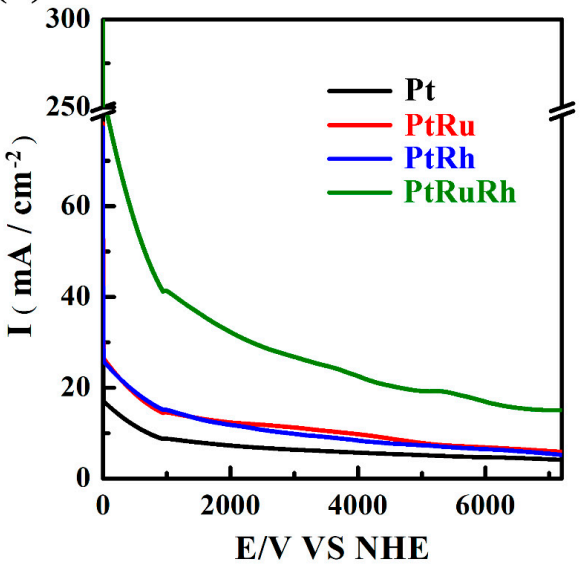

Figure 4. (a) CO-stripping voltammograms, (b) CV diagrams, (c) ethanol oxidation reaction (EOR) performance, and (d) CA curves of catalysts at a constant potential of $0.6 \mathrm{~V}$ vs. the normal hydrogen electrode (NHE) for Pt, PtRu, PtRh, and PtRuRh.

On the other hand, the CV diagrams of $\mathrm{Pt}, \mathrm{PtRu}, \mathrm{PtRh}$, and $\mathrm{PtRuRh}$ catalysts are shown in Figure $4 b$, and the areas under the curves of the hydrogen desorption region used to calculate the 
$\mathrm{ECSA}_{\mathrm{H}}$ for each catalyst are displayed in Table 1. The ECSA $\mathrm{H}_{\mathrm{H}}$ of ternary catalysts are also larger than those of $\mathrm{Pt}$ and binary ones, suggesting better Pt utilization from the former. However, when comparing the calculated ECSA $\mathrm{CO}$ with $\mathrm{ECSA}_{\mathrm{H}}$, large differences are noted for the same catalysts. This phenomenon has been reported by Vidaković et al., who suggest that the uncertainty of the COstripping method is the type of the $\mathrm{CO}$ bonding on the surface, rather than the H-adsorption method giving the maximum number of surface reactive Pt sites [51]. As a result, the $\mathrm{ECSA}_{\mathrm{H}}$ is relatively accurate compared to ECSA $\mathrm{CO}$.

Table 1. EOR performances of Pt, PtRu, PtRh, and PtRuRh catalysts.

\begin{tabular}{|c|c|c|c|c|c|c|c|}
\hline \multirow{2}{*}{ Sample } & \multirow{2}{*}{$\begin{array}{c}\operatorname{ECSA}_{H} \\
\left(\mathrm{~m}^{2} / \mathrm{g}_{(\mathrm{Pt})}\right)\end{array}$} & $\mathbf{I}_{06}$ & $I_{\max }$ & $\mathrm{SA}_{06}$ & $\mathbf{S A}_{\max }$ & \multirow{2}{*}{$\mathbf{I}_{\mathbf{f}} / \mathbf{I}_{\mathbf{b}}$} & \multirow{2}{*}{$\begin{array}{c}I_{06-7200} \\
\left(\mathrm{~A} / \mathrm{g}_{(\mathrm{Pt})}\right)\end{array}$} \\
\hline & & \multicolumn{2}{|c|}{$\left(\mathrm{A} / \mathrm{g}_{(\mathrm{Pt})}\right)$} & \multicolumn{2}{|c|}{$\left(\mathrm{mA} / \mathrm{cm}^{2}\left(\mathrm{ECSA}_{\mathrm{H}}\right)\right)$} & & \\
\hline $\mathrm{Pt}$ & 30.8 & 6.6 & 178.8 & 0.15 & 3.57 & 0.83 & 4.1 \\
\hline PtRu & 32.3 & 9.4 & 223.7 & 0.20 & 4.35 & 0.97 & 5.9 \\
\hline PtRh & 33.0 & 10.9 & 214.3 & 0.24 & 4.24 & 1.06 & 5.2 \\
\hline PtRuRh & 60.2 & 29.4 & 603.9 & 0.38 & 7.31 & 1.02 & 15.1 \\
\hline
\end{tabular}

The EOR performances of $\mathrm{Pt}, \mathrm{PtRu}, \mathrm{PtRh}$, and PtRuRh catalysts are summarized in Table 1, and their activities are shown in Figure 4c. All current densities are normalized by the ECSA $\mathrm{H}_{\mathrm{H}}$ and the potentials are also adjusted to the normal hydrogen electrode (NHE). Besides, specific activity at $0.6 \mathrm{~V}$ $\left(\mathrm{SA}_{06}\right)$, maximum specific activity $\left(\mathrm{SA}_{\max }\right)$, mass activity $(\mathrm{MA})$ at $0.6 \mathrm{~V}\left(\mathrm{I}_{06}\right)$ and the maximum MA $\left(\mathrm{I}_{\max }\right)$ of catalysts are also compared in Table 1 . It can be observed that the $\mathrm{SA}_{06}$ of the PtRuRh catalyst is $0.38 \mathrm{~mA} / \mathrm{cm}^{2}$, which is 2.5, 1.9, and 1.6 times higher than that of $\mathrm{Pt}, \mathrm{PtRu}$, and PtRh, respectively and superior to PtRu and PtRh-based ternary catalysts as compared in Table S4. In terms of MA, the $\mathrm{I}_{06}$ of PtRuRh catalyst is $29.4 \mathrm{~A} / \mathrm{g}_{(\mathrm{Pt})}$, which is $4.4,3.1$, and 2.7 times higher than that of Pt, PtRu, and PtRh, respectively. The rate determining step in the low potential region, such as $0.6 \mathrm{~V}$ is the dissociative adsorption of ethanol on surface Pt active sites [64-66]; therefore, high $\mathrm{SA}_{06}$ and $\mathrm{I}_{06}$ of $\mathrm{PtRuRh}$ also imply that the effective capability to dissociate ethanol on $\mathrm{Pt}$, attributed to the high ECSA and low onset potential towards CO-stripping. On the other side, the binary and ternary catalysts all provide higher $\mathrm{SA}_{\max }$ than Pt alone; especially $\mathrm{PtRuRh}$, which has the $\mathrm{SA}_{\max }$ of $7.31 \mathrm{~mA} / \mathrm{cm}^{2}$, owing to the presence of RuOx $[67,68]$ and RhOx [69] to promote EOR through the bifunctional mechanism, as reported in Table S3 and Figure 4c. Besides EOR performance, the forward anodic peak current density (If) to the backward peak current density (Ib), If/Ib ratios of binary and ternary [70] are also promoted due to the addition of the second and third metals. As can be seen in Table 1, If/Ib ratio increases from 0.83 to $0.97-1.02$, suggesting a better catalytic tolerance to carbonaceous species for the binary and ternary catalysts.

Moreover, in order to evaluate the stability of Pt, PtRu, PtRh, and PtRuRh catalysts, CA tests were carried out at $0.6 \mathrm{~V}$ in $0.5 \mathrm{M} \mathrm{H}_{2} \mathrm{SO}_{4}$ solution containing $1 \mathrm{M}$ ethanol for $7200 \mathrm{~s}$ and the results are exhibited in Figure 4d, and the MAs at $0.6 \mathrm{~V}$ after $7200 \mathrm{~s}\left(\mathrm{I}_{06-7200}\right)$ are summarized in Table 1 . As shown in Figure $4 \mathrm{~d}$, catalysts decay to different extents during CA tests owing to the poisoning of $\mathrm{Pt}$ surface active sites. Among them, PtRuRh shows the highest current density of $15.1 \mathrm{~A} / \mathrm{g}_{(\mathrm{Pt})}$ after EOR for $7200 \mathrm{~s}$, due to the bi-functional mechanism by the surface $\mathrm{Pt} / \mathrm{Ru} / \mathrm{Rh}$, where $\mathrm{Pt}$ provides active sites for ethanol adsorption and dissociation, and $\mathrm{Ru} / \mathrm{Rh}$ provide OCS for oxidating and removing the adsorbed intermediates formed during ethanol oxidation $[65,71]$.

\section{Conclusions}

In this study, in order to prepare highly effective EOR catalysts, Pt binary and ternary catalysts such as PtRu, PtRh, and PtRuRh have been synthesized. The addition of Ru and/or Rh in Pt can effectively promote the anti-poisoning ability and help the desorptions of adsorbed intermediates, especially for PtRu. Moreover, EOR activities are enhanced significantly through Ru and/or Rh addition, especially ternary $\mathrm{PtRuRh}$ with the $\mathrm{Pt} / \mathrm{Ru} / \mathrm{Ru}$ ratio of $80 / 5 / 15$, which both possess the highest $\mathrm{I}_{06}$ and 
$\mathrm{I}_{06-7200}$. This can be attributed to the co-existence of $\mathrm{RuO}_{x}$ and $\mathrm{RhO}_{x}$ onto surface that not only helps the formations of $\mathrm{CO}_{2}$ but also the removals of adsorbed intermediates, preventing $\mathrm{Pt}$ active sites from poisoning. Based on the above results, we can conclude that the addition of $\mathrm{Ru}$ and $\mathrm{Rh}$ into $\mathrm{Pt}$ catalysts can indeed enhance the activity and long-term performance of EOR. Therefore, carbon-supported PtRuRh NRs can be one of the most promising EOR catalysts.

Supplementary Materials: The following are available online at http://www.mdpi.com/2076-3417/10/11/3923/s1, Figure S1: XRD patterns, Table S1: SEM-EDS and XRD results, Table S2: XPS results, Table S3: CO-stripping results, and Table S4: comparison of EOR activity.

Author Contributions: Conceptualization, T.-H.H. and Y.-R.H.; methodology, T.-H.H.; validation, D.B., and S.L.; writing—original draft preparation, T.-H.H. and Y.-R.H.; writing—review and editing, T.-H.H. and K.-W.W. supervision, K.-W.W.; project administration, K.-W.W.; funding acquisition, K.-W.W. All authors have read and agreed to the published version of the manuscript.

Funding: This research was funded by Ministry of Science and Technology, R.O.C. (MOST 107-2628-E-008-003-MY3, MOST 108-3116-F-008-008, and MOST 108-3116-F-007-001. The authors like to thanks Prof. T.-Y. Chen for the funding support (Ministry of Science and Technology, Taiwan (MOST 109-3116-F-007-001 and MOST 106-2112-M-007-016-MY3)).

Conflicts of Interest: The authors declare no conflict of interest.

\section{References}

1. Li, M.; Cullen, D.A.; Sasaki, K.; Marinkovic, N.S.; More, K.; Adzic, R.R. Ternary Electrocatalysts for Oxidizing Ethanol to Carbon Dioxide: Making Ir Capable of Splitting C-C Bond. J. Am. Chem. Soc. 2013, 135, 132-141. [CrossRef]

2. Akhairi, M.A.F.; Kamarudin, S.K. Catalysts in direct ethanol fuel cell (DEFC): An overview. Int. J. Hydrog. Energy 2016, 41, 4214-4228. [CrossRef]

3. Tan, J.L.; De Jesus, A.M.; Chua, S.L.; Sanetuntikul, J.; Shanmugam, S.; Tongol, B.J.V.; Kim, H. Preparation and characterization of palladium-nickel on graphene oxide support as anode catalyst for alkaline direct ethanol fuel cell. Appl. Catal. A Gen. 2017, 531, 29-35. [CrossRef]

4. Bach Delpeuch, A.; Jacquot, M.; Chatenet, M.; Cremers, C. The influence of mass-transport conditions on the ethanol oxidation reaction (EOR) mechanism of Pt/C electrocatalysts. Phys. Chem. Chem. Phys. 2016, 18, 25169-25175. [CrossRef] [PubMed]

5. De Souza, R.F.B.; Parreira, L.S.; Silva, J.C.M.; Simões, F.C.; Calegaro, M.L.; Giz, M.J.; Camara, G.A.; Neto, A.O.; Santos, M.C. PtSnCe/C electrocatalysts for ethanol oxidation: DEFC and FTIR "in-situ" studies. Int. J. Hydrog. Energy 2011, 36, 11519-11527. [CrossRef]

6. Yu, W.; Porosoff, M.D.; Chen, J.G. Review of Pt-Based Bimetallic Catalysis: From Model Surfaces to Supported Catalysts. Chem. Rev. 2012, 112, 5780-5817. [CrossRef]

7. Kamarudin, M.Z.F.; Kamarudin, S.K.; Masdar, M.S.; Daud, W.R.W. Review: Direct ethanol fuel cells. Int. J. Hydrog. Energy 2013, 38, 9438-9453. [CrossRef]

8. Xu, Y.; Zhang, B. Recent advances in porous Pt-based nanostructures: Synthesis and electrochemical applications. Chem. Soc. Rev. 2014, 43, 2439-2450. [CrossRef]

9. Zhang, B.-W.; Sheng, T.; Wang, Y.-X.; Qu, X.-M.; Zhang, J.-M.; Zhang, Z.-C.; Liao, H.-G.; Zhu, F.-C.; Dou, S.-X.; Jiang, Y.-X.; et al. Platinum-Cobalt Bimetallic Nanoparticles with Pt Skin for Electro-Oxidation of Ethanol. ACS Catal. 2017, 7, 892-895. [CrossRef]

10. Antolini, E. Catalysts for direct ethanol fuel cells. J. Power Sources 2007, 170, 1-12. [CrossRef]

11. Zignani, S.C.; Baglio, V.; Linares, J.J.; Monforte, G.; Gonzalez, E.R.; Aricò, A.S. Endurance study of a solid polymer electrolyte direct ethanol fuel cell based on a Pt-Sn anode catalyst. Int. J. Hydrog. Energy 2013, 38, 11576-11582. [CrossRef]

12. González-Quijano, D.; Pech-Rodríguez, W.J.; Escalante-García, J.I.; Vargas-Gutiérrez, G.; Rodríguez-Varela, F.J. Electrocatalysts for ethanol and ethylene glycol oxidation reactions. Part I: Effects of the polyol synthesis conditions on the characteristics and catalytic activity of Pt-Sn/C anodes. Int. J. Hydrog. Energy 2014, 39, 16676-16685. [CrossRef]

13. Magee, J.W.; Zhou, W.-P.; White, M.G. Promotion of Pt surfaces for ethanol electro-oxidation by the addition of small SnO2 nanoparticles: Activity and mechanism. Appl. Catal. B Environ. 2014, 152-153, 397-402. [CrossRef] 
14. Shironita, S.; Sato, K.; Yoshitake, K.; Umeda, M. Pt-Ru/C anode performance of polymer electrolyte fuel cell under carbon dioxide atmosphere. Electrochim. Acta 2016, 206, 254-258. [CrossRef]

15. Garrick, T.R.; Diao, W.; Tengco, J.M.; Stach, E.A.; Senanayake, S.D.; Chen, D.A.; Monnier, J.R.; Weidner, J.W. The Effect of the Surface Composition of Ru-Pt Bimetallic Catalysts for Methanol Oxidation. Electrochim. Acta 2016, 195, 106-111. [CrossRef]

16. Jeon, T.-Y.; Lee, K.-S.; Yoo, S.J.; Cho, Y.-H.; Kang, S.H.; Sung, Y.-E. Effect of Surface Segregation on the Methanol Oxidation Reaction in Carbon-Supported Pt-Ru Alloy Nanoparticles. Langmuir 2010, 26, 9123-9129. [CrossRef]

17. Du, W.; Yang, G.; Wong, E.; Deskins, N.A.; Frenkel, A.I.; Su, D.; Teng, X. Platinum-Tin Oxide Core-Shell Catalysts for Efficient Electro-Oxidation of Ethanol. J. Am. Chem. Soc. 2014, 136, 10862-10865. [CrossRef]

18. Themsirimongkon, S.; Sarakonsri, T.; Lapanantnoppakhun, S.; Jakmunee, J.; Saipanya, S. Carbon nanotube-supported Pt-Alloyed metal anode catalysts for methanol and ethanol oxidation. Int. J. Hydrog. Energy 2019, 44, 30719-30731. [CrossRef]

19. Lu, S.; Eid, K.; Ge, D.; Guo, J.; Wang, L.; Wang, H.; Gu, H. One-pot synthesis of PtRu nanodendrites as efficient catalysts for methanol oxidation reaction. Nanoscale 2017, 9, 1033-1039. [CrossRef]

20. Wang, Q.; Wang, G.; Tao, H.; Li, Z.; Han, L. Highly CO tolerant PtRu/PtNi/C catalyst for polymer electrolyte membrane fuel cell. RSC Adv. 2017, 7, 8453-8459. [CrossRef]

21. Schmidt, V.M.; Ianniello, R.; Pastor, E.; González, S. Electrochemical Reactivity of Ethanol on Porous Pt and PtRu: Oxidation/Reduction Reactions in $1 \mathrm{M} \mathrm{HClO4.} \mathrm{J.} \mathrm{Phys.} \mathrm{Chem.} \mathrm{1996,} \mathrm{100,} \mathrm{17901-17908.} \mathrm{[CrossRef]}$

22. Yang, Z.; Yu, X.; Zhang, Q. Remarkably stable CO tolerance of a PtRu electrocatalyst stabilized by a nitrogen doped carbon layer. RSC Adv. 2016, 6, 114014-114018. [CrossRef]

23. Zhou, W.; Li, M.; Zhang, L.; Chan, S.H. Supported PtAu catalysts with different nano-structures for ethanol electrooxidation. Electrochim. Acta 2014, 123, 233-239. [CrossRef]

24. Liu, L.; Chen, L.-X.; Wang, A.-J.; Yuan, J.; Shen, L.; Feng, J.-J. Hydrogen bubbles template-directed synthesis of self-supported AuPt nanowire networks for improved ethanol oxidation and oxygen reduction reactions. Int. J. Hydrog. Energy 2016, 41, 8871-8880. [CrossRef]

25. Cao, X.; Wang, N.; Han, Y.; Gao, C.; Xu, Y.; Li, M.; Shao, Y. PtAg bimetallic nanowires: Facile synthesis and their use as excellent electrocatalysts toward low-cost fuel cells. Nano Energy 2015, 12, 105-114. [CrossRef]

26. Kim, S.-M.; Jo, Y.-G.; Lee, S.-Y. The composition-controlled synthesis of Pt-Ag bimetallic nanochains for catalytic methanol oxidation. Electrochim. Acta 2015, 174, 1244-1252. [CrossRef]

27. Wang, Y.; Zang, J.; Dong, L.; Pan, H.; Yuan, Y.; Wang, Y. Graphitized nanodiamond supporting PtNi alloy as stable anodic and cathodic electrocatalysts for direct methanol fuel cell. Electrochim. Acta 2013, 113, 583-590. [CrossRef]

28. Hao, Y.; Wang, X.; Zheng, Y.; Shen, J.; Yuan, J.; Wang, A.-J.; Niu, L.; Huang, S. Size-controllable synthesis of ultrafine PtNi nanoparticles uniformly deposited on reduced graphene oxide as advanced anode catalysts for methanol oxidation. Int. J. Hydrog. Energy 2016, 41, 9303-9311. [CrossRef]

29. Mukherjee, P.; Roy, P.S.; Bhattacharya, S.K. Improved carbonate formation from ethanol oxidation on nickel supported Pt-Rh electrode in alkaline medium at room temperature. Int. J. Hydrog. Energy 2015, 40, 13357-13367. [CrossRef]

30. Zhang, F.; Zhou, D.; Zhang, Z.; Zhou, M.; Wang, Q. Preparation of Rh/C and its high electro-catalytic activity for ethanol oxidation in alkaline media. RSC Adv. 2015, 5, 91829-91835. [CrossRef]

31. Higuchi, E.; Takase, T.; Chiku, M.; Inoue, H. Preparation of ternary Pt/Rh/SnO2 anode catalysts for use in direct ethanol fuel cells and their electrocatalytic activity for ethanol oxidation reaction. J. Power Sources 2014, 263, 280-287. [CrossRef]

32. Bach Delpeuch, A.; Maillard, F.; Chatenet, M.; Soudant, P.; Cremers, C. Ethanol oxidation reaction (EOR) investigation on $\mathrm{Pt} / \mathrm{C}, \mathrm{Rh} / \mathrm{C}$, and Pt-based bi- and tri-metallic electrocatalysts: A DEMS and in situ FTIR study. Appl. Catal. B Environ. 2016, 181, 672-680. [CrossRef]

33. Yoo, J.S.; Kim, H.T.; Joh, H.-I.; Kim, H.; Moon, S.H. Preparation of a CO-tolerant PtRuxSny/C electrocatalyst with an optimal $\mathrm{Ru} / \mathrm{Sn}$ ratio by selective $\mathrm{Sn}$-deposition on the surfaces of Pt and Ru. Int. J. Hydrog. Energy 2011, 36, 1930-1938. [CrossRef]

34. Yang, S.; Zhao, C.; Ge, C.; Dong, X.; Liu, X.; Liu, Y.; Fang, Y.; Wang, H.; Li, Z. Ternary Pt-Ru-SnO2 hybrid architectures: Unique carbon-mediated 1-D configuration and their electrocatalytic activity to methanol oxidation. J. Mater. Chem. 2012, 22, 7104-7107. [CrossRef] 
35. Huang, T.-H.; Zheng, H.-S.; Cheng, Y.-M.; Liu, C.-W.; Lee, S.-W.; Wang, J.-H.; Wang, K.-W. The preparation and mechanistic study of highly effective PtSnRu ternary nanorod catalysts toward the ethanol oxidation reaction. Sustain. Energy Fuels 2019, 3, 3352-3362. [CrossRef]

36. Xu, Z.-F.; Wang, Y. Effects of Alloyed Metal on the Catalysis Activity of Pt for Ethanol Partial Oxidation: Adsorption and Dehydrogenation on Pt3M (M = Pt, Ru, Sn, Re, Rh, and Pd). J. Phys. Chem. C 2011, 115, 20565-20571. [CrossRef]

37. Sheng, T.; Sun, S.-G. Insight into the promoting role of Rh doped on $\mathrm{Pt}(111)$ in methanol electro-oxidation. J. Electroanal. Chem. 2016, 781, 24-29. [CrossRef]

38. Rao, L.; Jiang, Y.-X.; Zhang, B.-W.; Cai, Y.-R.; Sun, S.-G. High activity of cubic PtRh alloys supported on graphene towards ethanol electrooxidation. Phys. Chem. Chem. Phys. 2014, 16, 13662-13671. [CrossRef]

39. Kawaguchi, T.; Rachi, Y.; Sugimoto, W.; Murakami, Y.; Takasu, Y. Performance of ternary PtRuRh/C electrocatalyst with varying Pt:Ru:Rh ratio for methanol electro-oxidation. J. Appl. Electrochem. 2006, 36, 1117-1125. [CrossRef]

40. Li, T.; Bagot, P.A.J.; Marquis, E.A.; Tsang, S.C.E.; Smith, G.D.W. Characterization of Oxidation and Reduction of Pt-Ru and Pt-Rh-Ru Alloys by Atom Probe Tomography and Comparison with Pt-Rh. J. Phys. Chem. C 2012, 116, 17633-17640. [CrossRef]

41. Luo, Z.; Lu, J.; Flox, C.; Nafria, R.; Genç, A.; Arbiol, J.; Llorca, J.; Ibáñez, M.; Morante, J.R.; Cabot, A. Pd2Sn [010] nanorods as a highly active and stable ethanol oxidation catalyst. J. Mater. Chem. A 2016, 4, 16706-16713. [CrossRef]

42. Dai, S.; Huang, T.-H.; Yan, X.; Yang, C.-Y.; Chen, T.-Y.; Wang, J.-H.; Pan, X.; Wang, K.-W. Promotion of Ternary Pt-Sn-Ag Catalysts toward Ethanol Oxidation Reaction: Revealing Electronic and Structural Effects of Additive Metals. ACS Energy Lett. 2018, 3, 2550-2557. [CrossRef]

43. He, Y.-B.; Li, G.-R.; Wang, Z.-L.; Ou, Y.-N.; Tong, Y.-X. Pt Nanorods Aggregates with Enhanced Electrocatalytic Activity toward Methanol Oxidation. J. Phys. Chem. C 2010, 114, 19175-19181. [CrossRef]

44. Tseng, Y.-C.; Chen, H.-S.; Liu, C.-W.; Yeh, T.-H.; Wang, K.-W. The effect of alloying on the oxygen reduction reaction activity of carbon-supported PtCu and PtPd nanorods. J. Mater. Chem. A 2014, 2, 4270-4275. [CrossRef]

45. Scofield, M.E.; Koenigsmann, C.; Wang, L.; Liu, H.; Wong, S.S. Tailoring the composition of ultrathin, ternary alloy PtRuFe nanowires for the methanol oxidation reaction and formic acid oxidation reaction. Energy Environ. Sci. 2015, 8, 350-363. [CrossRef]

46. Song, P.; Li, S.-S.; He, L.-L.; Feng, J.-J.; Wu, L.; Zhong, S.-X.; Wang, A.-J. Facile large-scale synthesis of $\mathrm{Au}-\mathrm{Pt}$ alloyed nanowire networks as efficient electrocatalysts for methanol oxidation and oxygen reduction reactions. RSC Adv. 2015, 5, 87061-87068. [CrossRef]

47. Zhou, W.-P.; Li, M.; Koenigsmann, C.; Ma, C.; Wong, S.S.; Adzic, R.R. Morphology-dependent activity of Pt nanocatalysts for ethanol oxidation in acidic media: Nanowires versus nanoparticles. Electrochim. Acta 2011, 56, 9824-9830. [CrossRef]

48. Shen, Y.; Gong, B.; Xiao, K.; Wang, L. In Situ Assembly of Ultrathin PtRh Nanowires to Graphene Nanosheets as Highly Efficient Electrocatalysts for the Oxidation of Ethanol. ACS Appl. Mater. Interfaces 2017, 9, 3535-3543. [CrossRef]

49. Ding, K.; Zhao, Y.; Liu, L.; Cao, Y.; Wang, Q.; Gu, H.; Yan, X.; Guo, Z. Pt-Ni bimetallic composite nanocatalysts prepared by using multi-walled carbon nanotubes as reductants for ethanol oxidation reaction. Int. J. Hydrog. Energy 2014, 39, 17622-17633. [CrossRef]

50. Vidaković, T.; Christov, M.; Sundmacher, K. The use of CO stripping for in situ fuel cell catalyst characterization. Electrochim. Acta 2007, 52, 5606-5613. [CrossRef]

51. You, D.J.; Kwon, K.; Joo, S.H.; Kim, J.H.; Kim, J.M.; Pak, C.; Chang, H. Carbon-supported ultra-high loading Pt nanoparticle catalyst by controlled overgrowth of Pt: Improvement of Pt utilization leads to enhanced direct methanol fuel cell performance. Int. J. Hydrog. Energy 2012, 37, 6880-6885. [CrossRef]

52. Antolini, E. Effect of the Structural Characteristics of Binary Pt-Ru and Ternary Pt-Ru-M Fuel Cell Catalysts on the Activity of Ethanol Electrooxidation in Acid Medium. ChemSusChem 2013, 6, 966-973. [CrossRef] [PubMed]

53. Hu, Y.; Zhu, A.; Zhang, Q.; Liu, Q. Preparation of PtRu/C core-shell catalyst with polyol method for alcohol oxidation. Int. J. Hydrog. Energy 2016, 41, 11359-11368. [CrossRef]

54. Wang, H.; Chen, S.; Wang, C.; Zhang, K.; Liu, D.; Haleem, Y.A.; Zheng, X.; Ge, B.; Song, L. Role of Ru Oxidation Degree for Catalytic Activity in Bimetallic Pt/Ru Nanoparticles. J. Phys. Chem. C 2016, 120, 6569-6576. [CrossRef] 
55. Papaderakis, A.; Pliatsikas, N.; Prochaska, C.; Papazisi, K.; Balomenou, S.; Tsiplakides, D.; Patsalas, P.; Sotiropoulos, S. Ternary Pt-Ru-Ni catalytic layers for methanol electrooxidation prepared by electrodeposition and galvanic replacement. Front. Chem. 2019, 2. [CrossRef] [PubMed]

56. Wang, K.-W.; Huang, S.-Y.; Yeh, C.-T. Promotion of Carbon-Supported Platinum-Ruthenium Catalyst for Electrodecomposition of Methanol. J. Phys. Chem. C 2007, 111, 5096-5100. [CrossRef]

57. Wei, Y.-C.; Liu, C.-W.; Chang, W.-J.; Wang, K.-W. Promotion of Pt-Ru/C catalysts driven by heat treated induced surface segregation for methanol oxidation reaction. J. Alloy. Compd. 2011, 509, 535-541. [CrossRef]

58. Fang, L.; Vidal-Iglesias, F.J.; Huxter, S.E.; Attard, G.A. A study of the growth and CO electrooxidation behaviour of PtRh alloys on Pt $\{100\}$ single crystals. J. Electroanal. Chem. 2008, 622, 73-78. [CrossRef]

59. De la Fuente, J.L.G.; Pérez-Alonso, F.J.; Martínez-Huerta, M.V.; Peña, M.A.; Fierro, J.L.G.; Rojas, S. Identification of $\mathrm{Ru}$ phases in PtRu based electrocatalysts and relevance in the methanol electrooxidation reaction. Catal. Today 2009, 143, 69-75. [CrossRef]

60. Di Noto, V.; Negro, E. A new Pt-Rh carbon nitride electrocatalyst for the oxygen reduction reaction in polymer electrolyte membrane fuel cells: Synthesis, characterization and single-cell performance. J. Power Sources 2010, 195, 638-648. [CrossRef]

61. Ochal, P.; Gomez de la Fuente, J.L.; Tsypkin, M.; Seland, F.; Sunde, S.; Muthuswamy, N.; Rønning, M.; Chen, D.; Garcia, S.; Alayoglu, S.; et al. CO stripping as an electrochemical tool for characterization of Ru@Pt core-shell catalysts. J. Electroanal. Chem. 2011, 655, 140-146. [CrossRef]

62. Wang, D.; Wang, J.; Lu, S.; Jiang, S.P. Facile synthesis of sub-monolayer Sn, Ru, and RuSn decorated Pt/C nanoparticles for formaldehyde electrooxidation. J. Electroanal. Chem. 2014, 712, 55-61. [CrossRef]

63. Lima, F.H.B.; Gonzalez, E.R. Ethanol electro-oxidation on carbon-supported Pt-Ru, Pt-Rh and Pt-Ru-Rh nanoparticles. Electrochim. Acta 2008, 53, 2963-2971. [CrossRef]

64. Zhu, M.; Sun, G.; Xin, Q. Effect of alloying degree in PtSn catalyst on the catalytic behavior for ethanol electro-oxidation. Electrochim. Acta 2009, 54, 1511-1518. [CrossRef]

65. Liu, C.-W.; Chang, Y.-W.; Wei, Y.-C.; Wang, K.-W. The effect of oxygen containing species on the catalytic activity of ethanol oxidation for PtRuSn/C catalysts. Electrochim. Acta 2011, 56, 2574-2581. [CrossRef]

66. Beyhan, S.; Léger, J.-M.; Kadırgan, F. Understanding the influence of Ni, Co, Rh and Pd addition to PtSn/C catalyst for the oxidation of ethanol by in situ Fourier transform infrared spectroscopy. Appl. Catal. B Environ. 2014, 144, 66-74. [CrossRef]

67. González-Quijano, D.; Pech-Rodríguez, W.J.; González-Quijano, J.A.; Escalante-García, J.I.; Vargas-Gutiérrez, G.; Alonso-Lemus, I.; Rodríguez-Varela, F.J. Electrocatalysts for ethanol and ethylene glycol oxidation reactions. Part II: Effects of the polyol synthesis conditions on the characteristics and catalytic activity of Pt-Ru/C anodes. Int. J. Hydrog. Energy 2015, 40, 17291-17299. [CrossRef]

68. Dinesh, B.; Saraswathi, R. Enhanced performance of Pt and Pt-Ru supported PEDOT-RGO nanocomposite towards methanol oxidation. Int. J. Hydrog. Energy 2016, 41, 13448-13458. [CrossRef]

69. Bach Delpeuch, A.; Chatenet, M.; Rau, M.S.; Cremers, C. Influence of H- and OH-adsorbates on the ethanol oxidation reaction-A DEMS study. Phys. Chem. Chem. Phys. 2015, 17, 10881-10893. [CrossRef]

70. Maiyalagan, T.; Alaje, T.O.; Scott, K. Highly Stable Pt-Ru Nanoparticles Supported on Three-Dimensional Cubic Ordered Mesoporous Carbon (Pt-Ru/CMK-8) as Promising Electrocatalysts for Methanol Oxidation. J. Phys. Chem. C 2012, 116, 2630-2638. [CrossRef]

71. Sedighi, M.; Rostami, A.A.; Alizadeh, E. Enhanced electro-oxidation of ethanol using Pt-CeO2 electrocatalyst prepared by electrodeposition technique. Int. J. Hydrog. Energy 2017, 42, 4998-5005. [CrossRef]

(C) 2020 by the authors. Licensee MDPI, Basel, Switzerland. This article is an open access article distributed under the terms and conditions of the Creative Commons Attribution (CC BY) license (http://creativecommons.org/licenses/by/4.0/). 